\title{
Arsenic Poisoning: The Risk, Clinical Features and Treatment
}

\author{
Bala Alkali Mohammed ${ }^{1}$, David B Oshevire ${ }^{2}$, Mohammed A King ${ }^{3}$, Rhamatallah A Alawode ${ }^{4,6}$, \\ Abdullateef Lawal ${ }^{5}$, Bisola S Babalola ${ }^{6}$ and Bashir Lawal ${ }^{1 *}$ \\ ${ }^{1}$ Department of Biochemistry, Federal University of Technology, Minna Nigeria \\ ${ }^{2}$ Senior Medical Officer, Hayok Medicare, Abuja \\ ${ }^{3}$ Department of Chemical Sciences, Biochemistry Unit Federal Polytechnic P.M.B. 55, Bida, Niger State, Nigeria
}

${ }^{4}$ Forestry Research Institute of Nigeria -Southern Guinea Research Station Mokwa, Nigeria

${ }^{5}$ Department of Chemistry, University of Ilorin, Nigeria

${ }^{6}$ Department of Chemistry, Federal University of Technology, Minna Nigeria

*Corresponding author: Lawal Bashir, Department of Biochemistry, Federal University of Technology, Minna Nigeria

\begin{tabular}{|c|c|}
\hline ARTICLE INFO & ABSTRACT \\
\hline $\begin{array}{l}\text { Received: 幽 September 28, } 2020 \\
\text { Published: } \text { 幽 October 08, } 2020\end{array}$ & $\begin{array}{l}\text { Environmental exposure to arsenic, is a major concern in many industrialized } \\
\text { countries. Although metals occur naturally in the environment but human activities } \\
\text { cause more metals releases and have altered the natural cycling of the elements. These }\end{array}$ \\
\hline $\begin{array}{l}\text { Citation: Mohammed Alkali Bala, } \\
\text { Oshevire B David, King A Mohammed, } \\
\text { Alawode A Rhamatallah, Lawal } \\
\text { Abdullateef, Babalola S Bisola, Lawal } \\
\text { Bashir. Arsenic Poisoning: The Risk, } \\
\text { Clinical Features and Treatment. Biomed } \\
\text { J Sci \& Tech Res 31(1)-2020. BJSTR. } \\
\text { MS.ID.005042. }\end{array}$ & $\begin{array}{l}\text { and metals related occupational exposure like leaded gasoline, industrial processes } \\
\text { such as smelting of lead and its combustion, pottery, boat building, mining industry, } \\
\text { exhaust fumes of vehicles, metal based painting, metal containing pipes, battery } \\
\text { recycling, grids, arm industry, pigments, printing of books, etc Exposure to arsenic may } \\
\text { affect nutrient metabolism and can cause a variety of health effects in human. Cancer, } \\
\text { immunotoxicity, hepatotoxicicty, neurotoxicity, nephrotoxicity, brain damage, lungs } \\
\text { damage, gastrointestinal distress and haematological alterations are the most frequently }\end{array}$ \\
\hline $\begin{array}{l}\text { Keywords: Arsenic; Toxicity; Health } \\
\text { Effect; Diagnosis; Treatment }\end{array}$ & $\begin{array}{l}\text { this paper provide a deep understanding of arsenic, their sources, routes of exposure, the } \\
\text { mechanisms of occasioning their toxicity, health implications in human and to identify } \\
\text { substances that contribute to overcome their hazardous effects in human. }\end{array}$ \\
\hline
\end{tabular}

\section{Introduction}

Heavy metals are metallic element with specific density of $>$ $5 \mathrm{~g} / \mathrm{cm}^{3}$ and are present in little quantity (ppb range to less than $10 \mathrm{ppm}$ ) in various environmental matrices [1,2]. They include lead, mercury, aluminum, arsenic, cadmium, nickel etc. Their wide ranges of application in agriculture, medicine and industrial have led to their wide environmental distribution and have call for concern over their potential effects on human health and the environment [2]. They are present in our body at a low concentration but can adversely affect the environment and living organisms [3]. Their presence in soil, water, food, atmosphere even in traces, can cause serious problems to all organisms. These exposures occur mostly through environmental contamination, occupational exposure, and accumulation in water, and food such as fish and vegetables. It is suggested that exposure to one heavy metal is usually associated with exposure to the others, thus synergetic toxicity of these heavy metals is expected. The bioavailability of these heavy metals are influenced by physical factors (phase association, temperature, adsorption and sequestration), chemical factors (kinetics, thermodynamic equilibrium and lipid solubility) and biological factors (species difference, trophic interactions, and physiological/ biochemical adaptation) $[2,4,5]$.

They are ranked among the top 10 of hazardous substances on the basis of the toxicity and the potential for exposure from water, soil, and air contamination [6]. Cadmium, lead, arsenic 
and mercury have been implicated with majority of heavy metal associated disease in primary care medicine [7]. Heavy metals exert deleterious health effects by generating reactive oxygen species, which altered the integrity of DNA, induced lipid peroxidation, and reduction of protein sulfhydryls [8]. These greatly affect the integrity of vital organs particularly to the liver, nervous system, and kidneys [9]. The implicative role of heavy metal intoxication in cancer and cardiovascular disease (CVD) is also well documented $[10,11]$. Although the cardiovascular system is not the primary target of heavy metal toxicity, Heavy metal induced degradation of antioxidant system leading to oxidative stress in the cells as a major effect of their environmental exposure [11]. The first step towards managing heavy metal poisoning is the removal of the victim from the source of exposure and the lessening of total body burden. Antioxidants particularly endogenous dietary antioxidants from natural products [12] are the important preventive and curative factors to be considered in heavy metal intoxication. The main focus of this review is to provide insight into the sources of arsenic and mercury contamination, mechanism of toxicity, various organs they affect in human body and their harmful effects on the environment and living organisms.

\section{Arsenic}

Arsenic is a chemical element with atomic number 33 and chemical symbol As. It occurs as pure elemental crystal or in combination with metals and sulfur. Arsenic is a metalloid with various allotropes, but only the gray form, which has a metallic appearance, is important to industry [2]

\section{Occurrence, Sources and Human Exposure}

Arsenic is one of the most important heavy metals with semimetallic property that occur at low concentrations in inorganic forms of trivalent arsenite (AsIII) and the pentavalent arsenate (AsV). About 90\% of ingested arsenic is absorbed by the gastrointestinal tract [8]. However, pentavalent arsenicals (AsV) show a lower uptake rate and accumulation in the cellular system than trivalent species (AsIII) [13]. In addition, trivalent arsenite (AsIII) have high affinity for sulhydryl $(-\mathrm{SH})$ groups of proteins than the pentavalent arsenate (AsV), thus making it more toxic than its counterpart, AsV [14]. It is widely available in the form of sulfides, oxides or salt of sodium, iron, copper, and calcium [15]. Sources of arsenic contamination in human include soil, air, food and drinking water due to contamination from arsenic containing industrial effluent, agricultural pesticide, or natural mineral deposition. Its contamination of drinking water poses serious global environmental disaster [16]. About 200 million people are exposed to arsenic at level above the prescribed limit through drinking water [17]. Food particularly, staple crop such as rice provide the largest source of arsenic exposure. In view of the global consumption of rice and greater risk of contamination through this crop, a maximum permissible limit of arsenic in white and brown rice has been set to 200 and $400 \mu \mathrm{g} / \mathrm{kg}$ respectively by World Health Organization (WHO) guidelines [18].
Arsenic poisoning may also occur in case of suicidal or accidental intake of arsenic containing pesticides, insecticides, or other chemicals [19]. Environmental exposure due to natural phenomena such as erosion, anthropogenic activities and volcanic eruptions has been reported [20]. Human exposure to this heavy metal may occur orally, inhalation and through dermal contact $[2,21]$.The concentrations of arsenic in air varies with locations , it ranged between 1 and $3 \mathrm{ng} / \mathrm{m}^{3}$ in remote area, and ranged between 20 to $100 \mathrm{ng} / \mathrm{m}^{3}$ in cities [2,21]. Its concentration also ranges between 20 to $140 \mathrm{ng} / \mathrm{kg}$ in foods [22], 1 to $40 \mathrm{mg} / \mathrm{kg}$ in soil [2], and less than $10 \mu \mathrm{g} / \mathrm{L}$ in water. However, the level of arsenic intake from water, soil and air are much lower than from food substances

\section{Mechanism of Arsenic Toxicity}

Arsenic is a protoplastic toxicant that primarily affects the sulphydryl group of cells and compromised the integrity of cell enzymes and cellular respiration [8]. During chronic arsenic exposure, harmful inorganic arsenic compounds are enzymatically methylated by humans and organisms (fungi, bacteria, and algae) to produce less harmful Monomethylarsonic Acid (MMA) and Dimethylarsinic Acid (DMA) and are which excreted through urine. These end products are considered reliable biomarker of chronic arsenic exposure [23]. However, Pigmentation and keratosis (Figure 1) are the specific skin lesions that indicate chronic arsenic toxicity [24]. The biotransformation occurs primarily in the liver, a reaction catalysed by S-adenosylmethionine (SAM) and Glutathione (GSH)/ NADPH dependent hepatic methyltransferases [25]. The methyl group is donated by S-adenosylmethionine (SAM) while the Glutathione (GSH) serves as the redundant [26,27]. However, other tissues such as heart, lung, bladder and kidney, and bladder have also reported for the expression of folate dependent methyltransferases [25]. Therefore, the binding of arsenic species to GSH enhanced the success of the biotransformation and increases its elimination from the body.

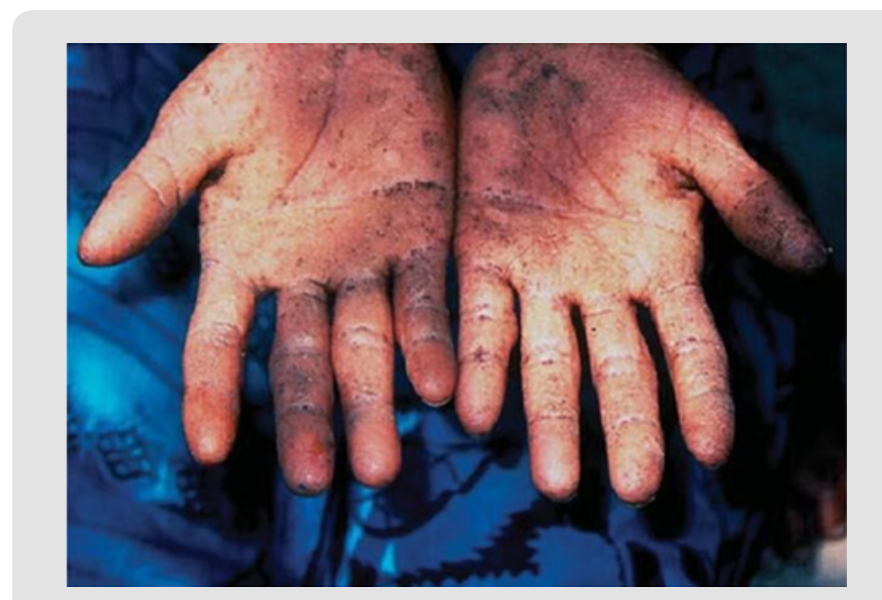

Figure 1: Arsenickeratosis[23]

Monomethylarsonic acid (MMA III), is an intermediate product generated during this biotransformation. It is considered more toxic than the parent compound due to the higher affinity for sulfhydryl 
$(-\mathrm{SH})$ groups [28]. It remains in the cell and cannot be excreted in the urine. Accumulation of this intermediate compound has been attributed to arsenic-induced carcinogenesis [15]. Evidence from in vivo and in vitro cytotoxicity study ranked the relative toxicities of arsenic metabolites in order; MMAIII > DMAIII > AsIII > AsV > MMAV > DMAV [8, 28,29].

\section{Clinical Features}

Arsenic has been classified as class 1 carcinogen by the International Agency for Research on Cancer [10]. It has been reported to cause cancer of the lungs, skin, urinary bladder, liver, and kidney [30]. Arsenic has been reported to be neurotoxic, teratogenic, embryotoxic and fetal growth retardation agent in animals [31]. It has also been reported to induce anemia, gastrointestinal effects, skin lesions (Figure 2), neuropathy, hyperpigmentation, vascular lesions, liver damage and renal damage [20]. Cardiovascular system, nervous system, pulmonary system, endocrine system, and reproductive system has also been reported to be adversely affected by chronic arsenic ingestion [32]. Maternal arsenic exposure has also been reported to adversely affect $\mathrm{T}$ cell and B cell [33]. However, Pigmentation and keratosis are the specific skin lesions that indicate chronic arsenic toxicity [24]. 2.4 Acute poisoning. Acute arsenic poisoning may also occur in case of suicidal or accidental intake of arsenic containing pesticides, insecticides, or other chemicals [19]. The LD50 of arsenic during acute exposure ranges between 100-300 mg [34].

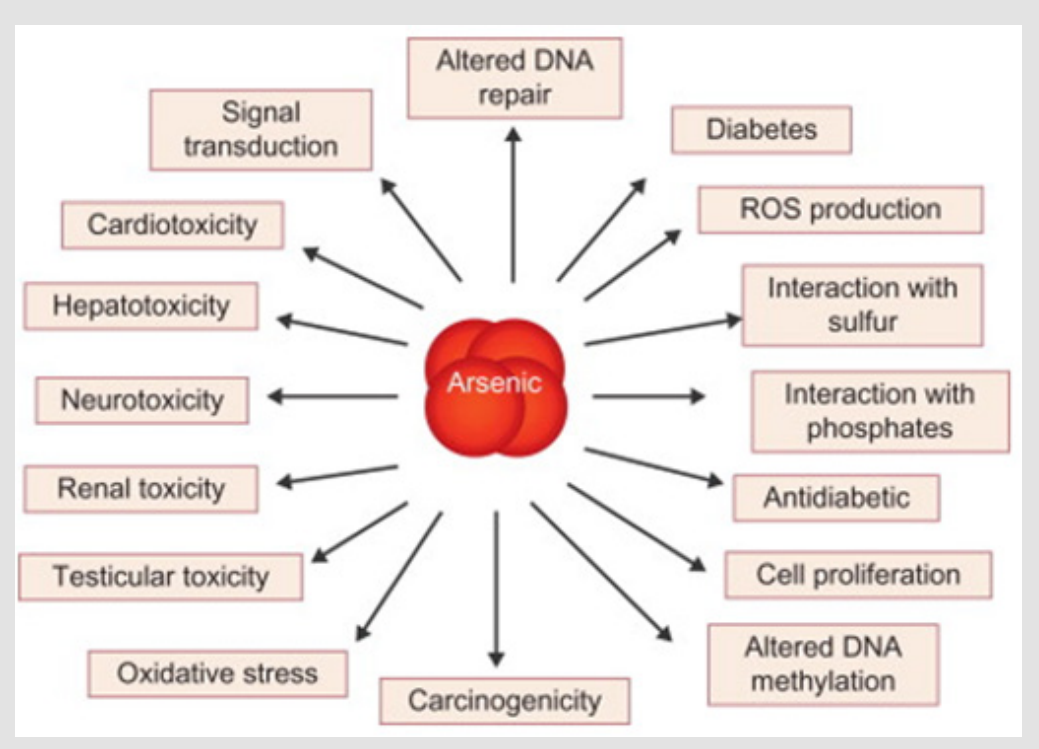

Figure 2: Mechanism for Arsenic-induced toxic effect.

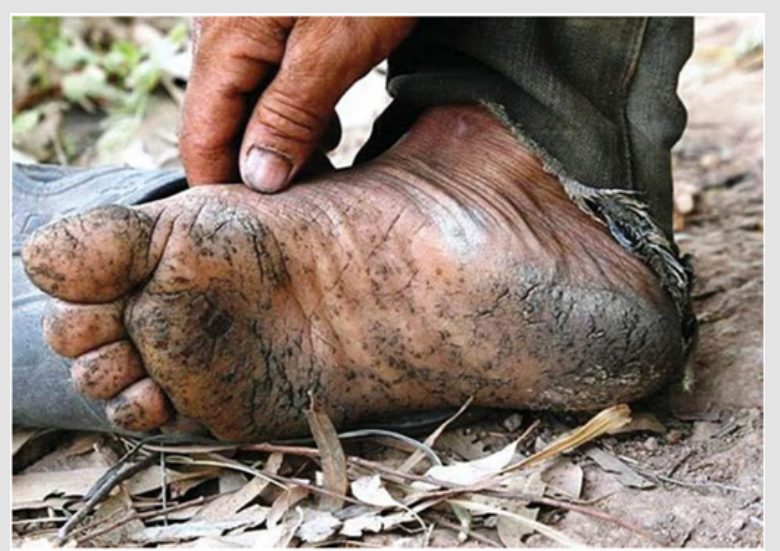

Figure 3: Skinlesions due to arsenicosis(adaptedfrom[36]).

However, information contained in the Risk Assessment Information System database states "The acute lethal dose of inorganic arsenic to humans has been estimated to be about 0.6 $\mathrm{mg} / \mathrm{kg} /$ day [35] However, a concentration less than $5 \mathrm{mg}$ arsenic exposure could lead to diarrhoea and vomiting that disappear 12 without treatment intervention [35]. Depending on the concentration of arsenic ingested, death usually occurs within 24 to 96 hours [34]. A case study of patient who consumed $8 \mathrm{~g}$ and $30 \mathrm{~g}$ of arsenic reported that death occur in 8 days and 15 hours respectively, despite treatment with arsenic antidote (British anti-lewisite) and gastric lavage intervention [36,37]. The clinical features of acute arsenic poisoning are relating to disturbed gastrointestinal system such as profuse watery diarrhoea (choleroid diarrhoea). due to increased permeability of the blood vessels [34], vomiting, nausea and colicky abdominal pain, that mimic an acute abdomen [38] Other clinical features include excessive salivation, diffuse skin rash, acute psychosis, seizure and toxic cardiomyopathy [39].The massive fluid loss due to gastrointestinal tract secretion has different consequent effect ranging from severe dehydration, decrease volume of blood circulation to circulatory collapse [34], 
Gastritis, oesophagitis and hepatic steatosis are the commonly reported postmortem findings [35].

Intravascular coagulation, haemaglobinuria, bone marrow depression, normocytic normochromic anaemia, severe pancytopenia and basophilic stippling are the common Haematological alteration in acute arsenic poisoning [40]. Peripheral neuropathy is a common neurological symptoms of acute arsenic poisoning and may lead to severe weakness with demands of mechanical ventilation [40] , a condition similar to Guillain-Barré syndrome [41,42].Arsenic induce haemorrhage has also been attributed to encephalopathy and has been reported after intravenous administration of arsphenamines [43] Metabolic alteration including acidosis hypoglycaemia and hypocalcaemia has also been reported in human and animals expose to acute arsenic poisoning [44].

\section{Chronic Poisoning}

Chronic arsenic exposure has multisystem effect and the most serious consequence is malignancy [45]. However, geographical location, individual and population differences have a great impact in the manifestation of arsenic toxicity. Arsenic has been classified as class 1 carcinogen by the International Agency for Research on Cancer [10]. It has been reported to cause cancer of the lungs, skin, urinary bladder, liver, and kidney [30]. Arsenic has been reported to be neurotoxic, teratogenic, embryotoxic and foetal growth retardation agent in animals [31]. It has also been reported to induce anemia, gastrointestinal effects, skin lesions (Figure 3), neuropathy, hyperpigmentation, vascular lesions, and hepatorenal damage [20]. Cardiovascular system, nervous system, pulmonary system, endocrine system, and reproductive system has also been reported to be adversely affected by chronic arsenic ingestion [32]. Maternal arsenic exposure has also been reported to adversely affect T cell and B cell [33]. However, Pigmentation and keratosis are the specific skin lesions that indicate chronic arsenic toxicity [24] Skin (Dermatological changes).

Dermatological alterations particularly palmar, solar keratosis and hyperpigmentation are considered an initial and reliable diagnostic criterion for chronic arsenic exposure. The keratosis appear as a discrete nodules and uniform thickening [44], while the hyperpigmentation appears less discrete diffuse, dark brown spots of the skin [45]. Non-melanin pigmented skin are more susceptible to high basal cell carcinoma [46], with latent period of about 60 years. This has been documented in workers using arsenic pesticides, patients following treatment with Fowler's solution, and has been associated with consumption of arsenic contaminated wine [47]. Arsenic deposition in keratin-rich areas such as Mee's lines (white lines in the fingernails and toenails) has also been implicated [48]. High arsenic contamination in drinking water has been correlated with hyperpigmentation and keratosis in a report of population studies from West Bengal in India [44]. Poor nutritional status has been reported to enhanced arsenic poisoning induced dermatological changes [44]. However, [49] reported that arsenic induced skin lesions occur despite a good nutritional status of Atacameno people in northern Chile.

\section{Hepatic Impairment}

About $77 \%$ and $91.3 \%$ hepatomegaly and non-cirrhotic portal fibrosis were recorded in 248 patients exposed to chronic levels of arsenic in drinking water from West Bengal, India [44]. Chronic arsenic exposure has also been implicated incomplete septal cirrhosis in 5 of 42 patients exposed arsenic intoxication [50].

\section{Cardiovascular System}

Chronic arsenic exposure has been implicated in cardiac arrhythmias direct myocardial impairment and cardiomyopathy [3]. Effect of chronic arsenic poisoning on cardiovascular impairment has been reported in different woman populations. [3] reported high incidence of hypertension in 1481 Bangladesh population that were exposed to arsenic contaminated water. Similarly, [10] reported a significant increase in hypertensive heart disease induced mortality in a population of Millard County, USA that were exposed to arsenic. [16] also established a link between ischaemic heart disease and long term arsenic exposure in 74 Taiwan patients. Chronic exposure to arsenic from contaminated water has also been associated with peripheral vascular impairment in patient from Chile [17] and black foot disease, a peripheral vascular disease, which causes gangrene of the foot in south western coast of Taiwan. Swedish copper smelter have also been postulated to be highly susceptible to arsenic induced cardiovascular disease [18].

\section{Neurological System}

The neurological system is one of the sites for manifestation of arsenic intoxication. Most frequently encountered is finding is a Guillain-Barré syndrome-like peripheral neuropathy with similar electromyographic attribute. Arsenic intoxication also manifest in memory loss confusion, and behavioural changes. Temporal cognitive abnormalities have been documented in workers exposed to arsenic for 14-18 months. Cognitive stability was however achieved after withdrawal from the arsenic source increased prevalence of cerebral infarction and other cerebrovascular abnormalities, were recorded in 8102 population that were exposed to arsenic through contaminated water [29].

\section{Genitourinary System}

High level of arsenic contamination has been associated with adenocarcinomas of the bladder and transitional cell carcinomas of the kidney, bladder, ureter I Taiwan female and male population [30]. Arsenic induced nephritis and prostate cancer has also increase mortality rate in exposed patient. Carcinogenicity of arsenic has been postulated to be cell dependent and specific. However, contrary to this, [31] found an association between 
arsenic intoxication with bladder cancer risk but not kidney cancer. Arsenic exposure could be detrimental to the foetus; studies found out that placental arsenic concentration in pregnant women, who consumed $200 \mu \mathrm{g} / \mathrm{l}$ arsenic contaminated water was almost to 5 concentrations in non-expose pregnant women. Children under breastfeeding are also found vulnerable to arsenic intoxication from the mother.

\section{Respiratory System}

Chronic arsenic intoxication has been linked to obstructive and restrictive lung disease. Arsenic induced respiratory impairments or lung disease is more commonly observed in patients with the skin lesions. In concordance, Taiwan patients with black foot disease has been observed for increased incidence of bronchitis. Although the reason is not known, the possibility of increased deposition of arsenic in the lung has been postulated and supported by necropsy studies human.

\section{Diagnosis and Treatment}

The important biomarkers of arsenic exposure are the urinary excretion and its concentration in nail, hair, and urine. Arsenic is rapidly cleared off in the blood and thus could only reflect exposure for only a short period following absorption. Arsenic occurs in higher concentrations in human nails and hair than in other parts of the body [35]. This is due to the high keratin content in in human nails and hair. Arsenic concentration in hair increased in during arsenic intoxication. Arsenic concentrations ranging from 3 to 10 $\mathrm{mg} / \mathrm{kg}$ are common in populations of West Bengal that have high arsenic concentrations in drinking water. The inorganic arsenic has about 4 days half-life in humans, and urine is the major route of its excretion. Therefore, the urine concentration of arsenic has been used as an indicator of recent arsenic intoxication. The concentrations of arsenic in urine have also been correlated with arsenic intake in drinking-water. A total daily intake of $46 \mu \mathrm{g} / \mathrm{L}$ and $324 \mu \mathrm{g} / \mathrm{L}$ arsenic from drinking water produced $41 \mu \mathrm{g} / \mathrm{L}$ and 178 $\mu \mathrm{g} / \mathrm{L}$ concentrations of arsenic in urine respectively [34]. However, some sea and marine food contains nontoxic organo arsenic and arsenosugars. These compounds are not toxic to mammalian cells and thus may influence urinary levels of arsenic. In order to eliminate the contribution of complex organo arsenicals in urine and enhance the diagnosis accuracy, some clinical laboratories use method that specifically quantifies inorganic arsenic or its metabolites, dimethylarsonic acid and monomethy larsnoic acid. However, certain marine organisms, such as bivalves contain over $100 \mu \mathrm{g}$ of the metabolite (dimethylarsonic acid) and may thus elevate the urine arsenic levels when the above speciation methods of analysis are used. Thus, the urine arsenic measurement may not be an accurate indicator of as intoxication if there has been any consumption of seafood within the past 3 days. Treatment of arsenic poisoning depend on the manifested symptoms, first of all is the removal of the patient from the source of exposure. Application of chelating agent like succimer (2,3- dimercaptosuccinic acid, DMSA) and dimercaprol is paramount in patient with severe burden [34]. Patient with kidney failure should be considered with hemodialysis [35].

\section{Arsenic Interaction with Other Metal}

The interactions between arsenic and other heavy metals or with other toxicant may produce synergistic (stronger) or antagonistic (weaker) effect than when use singly [15]. It is suggested that exposure to one heavy metal is usually associated with exposure to the others, thus synergetic or antagonistic toxicity of these heavy metals is expected. A synergistic effect is established when two heavy metals interact and produce higher effect than individual metal alone while an antagonistic effect is established when two heavy metals interact and produce lower effect than individual metal alone [15].

\section{Conclusion}

The paper depicts arsenic's routes of exposure, their health impacts, diagnosis, and treatment. We are being exposed to myriads of such heavy metal though diet, inhalation from air and metal related occupational exposures. Arsenic may exist in the environment in different mixture. Some heavy metals interact synergistically that they impose health problems many times greater than their singly effect. The overwhelmed burden of chronic diseases due to arsenic intoxication is alarming, therefore a proper precaution measure in prevention of toxic exposures is needed.

\section{References}

1. Kabata- Pendia A (2001) Trace Elements in Soils and Plants. Boca Raton, FL CRC Press p: 331.

2. Tchounwou PB, Centeno JA, Patlolla AK (2004) Arsenic toxicity, mutagenesis, and carcinogenesis - a health risk assessment and management approach. Mol Cell Biochem 255: 47-55.

3. Rahman M, Tondel M, Ahmad SA, I A Chowdhury, M H Faruquee, et al. (1999) Hypertension and arsenic exposure in Bangladesh. Hypertension 33(1): 74-78.

4. Hamelink JL, Landrum PF, Harold BL, William BH (1994) Bioavailability: Physical, Chemical, and Biological Interactions. Boca Raton, FL: CRC Press Inc 1994

5. Verkleji JAS (1993) The effects of heavy metals stress on higher plants and their use as biomonitors In Plant as Bioindicators: Indicators of Heavy Metals in the Terrestrial Environment. Markert B editor. New York: VCH Pp: 415-424.

6. (2005) ATSDR (Agency for Toxic Substances and Disease Registry), “CERCLA Priority List of Hazzardous Substances," 2005.

7. Hu H (2000) “Exposure to metals.” Primary Care 27(4): 983-996.

8. Jan AT, Azam M, Siddiqui K, Ali A, Choi I, et al. (2015) Heavy Metals and Human Health: Mechanistic Insight into Toxicity and Counter Defense System of Antioxidants. Int J Mol Sci 16(12): 29592-29630.

9. Ibrahim D, Froberg, A Wolf, DE Rusyniak (2006) Heavy metal poisoning: clinical presentations and pathophysiology. Clinics in LaboratoryMedicine 26(1): 67-97. 
10. Lewis DR, Southwick JW, Ouellet Hellstrom R, J Rench, RL Calderon, et al. (1999) Drinking water arsenic in Utah: a cohort mortality study. Environ Health Perspect 107(5): 359-365.

11. Tsai SM, Wang TN, Ko YC (1999) Mortality for certain diseases in areas with high levels of arsenic in drinking water. Arch Environ Health 54(3): 186-193.

12. Lawal B, Shittu OK, Inje OF, Berinyuy EB, Muhammed H, et al. (2017) Potential Antioxidants and Hepatoprotectives from African Natural Products: A Review, Clinical Phytoscience 23(2): 1-66.

13. Flora SJS (2011) Arsenic-induced oxidative stress and its reversibility. Free Radic Biol Med 51(2): 257-281.

14. Hughes MF, Beck BD, Chen Y, Lewis AS, Thomas DJ, et al. (2011) Arsenic exposure and toxicology: A historical perspective. Toxicol Sci 123(2): 305-332.

15. Singh N, Gupta VK, Kumar A, Sharma B (2017) Synergistic Effects of Heavy Metals and Pesticides in Living Systems; Frontiers in Chemistry 5: 1-9.

16. Tsai SM, Wang TN, Ko YC (1998) Mortality for certain diseases in areas with high levels of arsenic in drinking water. Arch Environ Health 54(3): 186-193.

17. Borgono JM, Vincent P, Venturino H (1977) Arsenic in the drinking water of the city of Antigofasta: epidemiological and clinical study before and after installation of a treatment plant. Environ Health Perspect 19: 103105.

18. Axelson O, Dahlgren E, Jansson CD (1978) Arsenic exposure and mortality: a case-referent study from a Swedish copper smelter. Br J Ind Med 35(1): 8-15.

19. Sarah E Orr SE, Bridges CC (2017) Chronic Kidney Disease and Exposure to Nephrotoxic Metals-review. International Journal of Molecular Sciences 18(5): 1039.

20. (2007) Agency for Toxic Substances and Disease Registry (ATSDR, 2007). Toxicological Profile for Arsenic (Update). U.S. Public Health Service, U.S. Department of Health and Human Services, Atlanta, GA.

21. Tchounwou PB, Wilson B, Ishaque A (1999) Important considerations in the development of public health advisories for arsenic and arseniccontaining compounds in drinking water. Rev Environ Health 14(4): 211-229.

22. Morton WE, Dunnette, DA (1994) Health effects of environmental arsenic. In Nriagu JO (eds.), Arsenic in the Environment Part II: Human Health and Ecosystem Effects. John Wiley \& Son Inc, New York, p.17-34.

23. Jaishankar MTT, Tenzin Tseten, Anbalagan N, MathewBB, Beeregowda KN, et al. (2014) Toxicity, mechanism, and health effects of some heavy metals. Interdiscip Toxicol 7(2): 60-72.

24. Martin S, Griswold W (2009) Human health eff ects of heavy metals. Environmental Science and Technology Briefs for Citizens 15: 1-6.

25. Lin S, Shi Q, Nix FB, Styblo M, Beck MA, et al. (2002) A novel S-adenosylL-methionine: ArsenicIII methyltransferase from rat liver cytosol. J Biol Chem 277(13): 10795-10803.

26. Thomas DJ (2009) Unraveling arsenic-glutathione connections. Toxicol Sci 107(2): 309-311.

27. Waters SB, Devesa V, DelRazo LM, Styblo M, Thomas DJ, et al. (2004) Endogenous reductants support the catalytic function of recombinant rat cyt19, an arsenic methyltransferase. Chem Res Toxicol 17(3): 404409.

28. PetrickJS, Jagadish B, MashEA,Aposhian HV(2001) Monomethylarsonous acid (MMAIII) and arsenite: Ld (50) in hamsters and in vitro inhibition of pyruvate dehydrogenase. Chem Res Toxicol 14(6): 651-656.

29. Chiou HY, Huang WI, Su CL, Y H Hsu, C J Chen, et al. (1997) Doseresponse relationship between prevalence of cerebrovascular disease and ingested inorganic arsenic. Stroke 28(9): 1717-1723.
30. Guo HR, Chiang HS, Hu H, Stuart R Lipsitz, Richard R Monson, et al. (1997) Arsenic in drinking water and incidence of urinary cancers. Epidemiology 8: 545-50.

31. Kurttio P, Pukkala E, Kahelin H, A Auvinen, J Pekkanen et al. (1999) Arsenic concentrations in well water and risk of bladder and kidney cancer in Finland. Environ Health Perspect 107(9): 705-710.

32. Huy TB, Tuyet Hanh TT, Johnston R, Nguyen Viet H (2014) Assessing Health Risk due to Exposure to Arsenic in Drinking Water in Hanam Province, Vietnam. International Journal of Environmental Research and Public Health 11(8): 7575-7591.

33. Desta DD (2018) Environmental Xenobiotics and Their Adverse Health Impacts-A General Review. Journal of Environment Pollution and Human Health 6(3): 77-88.

34. Ratnaike RN (2003) Acute and chronic arsenic toxicity. Postgrad Med J 79: 391-396.

35. Opresko DM (1992) Risk Assessment Information System database, Oak Ridge Reservation Environmental Restoration Program.

36. Ghariani M, Adrien ML, Raucoules M, J Bayle, Y Jacomet, et al. (1991) Subacute arsenic poisoning. Ann Fr Anesth Reanim 10(3): 304-307.

37. Logemann E, Krutzfeldt B, Pollak S (1990) Suicidal administration of elemental arsenic. Arch Kriminol 185(3-4): 80-88.

38. Mueller PD, Benowitz NL (1989) Toxicologic causes of acute abdominal disorders. Emerg Med Clin North Am 7(3): 667-682.

39. Campbell JP, Alvarez JA (1989) Acute arsenic intoxication. Am Fam Physician40(6): 93-97.

40. Greenberg C, Davies S, McGowan T (1979) Acute respiratory failure following severe arsenic poisoning. Chest 76: 596-598.

41. Freeman JW, Couch JR (1978) Prolonged encephalopathy with arsenic poisoning. Neurology 28: 853-855.

42. Le Quesne PM (1982) Metal-induced diseases of the nervous system. Br J HospMed 28(5): 534-538.

43. Call RA, Gunn FD (1949) Arsenical encephalopathy. Arch Pathol 48(2): 119-128.

44. Guha Mazumder DN, Haque R, Ghosh N (1998) Arsenic levels in drinking water and the prevalence of skin lesions in West Bengal, India. Int J Epidemiol 27(5): 871-877.

45. Smith AH, Arroyo AP, Mazumdar DN, M J Kosnett, A L Hernandez, et al. (2000) Arsenic-induced skin lesions among Atacameno people in northern Chile despite good nutrition and centuries of exposure. Environ Health Perspect 108(7): 617-620.

46. Abernathy CO, Liu YP, Longfellow D, Aposhian HV, Beck B, et al. (1999) Arsenic: health effects, mechanisms of actions, and research issues. Environ Health Perspect 107(7): 593-597.

47. Everall JD, Dowd PM (1978) Influence of environmental factors excluding ultraviolet radiation on the incidence of skin cancer. Bull Cancer 65(3): 241-247.

48. Fincher RM, Koerker RM (1987) Long-term survival in acute arsenic encephalopathy. Follow-up using newer measures of electrophysiologic parameters. Am J Med 82(3): 549-552.

49. Santra A, Das Gupta J, De BK (1999) Hepatic manifestations in chronic arsenic toxicity. Indian J Gastroenterol 18(4): 152-155.

50. Nevens F, Staessen D, Sciot R, B Van Damme, V Desmet, et al. (1994) Clinical aspects of incomplete septal cirrhosis in comparison with macronodular cirrhosis.Gastroenterology 106(2): 459-463. 
ISSN: 2574-1241

DOI: $10.26717 /$ BJSTR.2020.31.005042

Lawal Bashir. Biomed J Sci \& Tech Res

(c) (P) This work is licensed under Creative Commons Attribution 4.0 License

Submission Link: https://biomedres.us/submit-manuscript.php

$\begin{array}{ll}\text { BIOMEDICAL } & \text { Assets of Publishing with us } \\ \text { RESEARCHES } & \text { - Global archiving of articles } \\ \text { - Immediate, unrestricted online access } \\ \text { - Rigorous Peer Review Process }\end{array}$

